\title{
A RAPID METHOD FOR DETECTING BACTERIA IN DRINKING WATER
}

\author{
JIYOUNG LEE and ROLF A. DEININGER \\ Department of Environmental \& Industrial Health \\ The University of Michigan \\ Ann Arbor, Michigan 48109
}

Accepted for Publication April 20, 1999

\begin{abstract}
$A$ rapid determination of the total bacterial count in drinking water is important to the operators of treatment plants and distribution systems. It will allow corrective measures in real-time, such as increasing the disinfectant dose or removing water that has high bacterial numbers. The present heterotrophic plate count (HPC) analysis takes seven days and is not useful for operational intervention. The purpose of this study was to determine if a rapid adenosine triphosphate (ATP) assay would estimate the total number of bacteria in minutes. For quality control purposes and also to test the accuracy of both the ATP and HPC test, direct enumeration of the bacteria in a water sample was done using two epifluorescence methods. One was acridine orange direct count (AODC) method, which allows enumeration of both viable and nonviable bacteria. The other was direct viable count $(D V C)$ method, which enumerates viable bacteria. Water samples originated from local, national, and international locations. The sample selection criteria were based on proximity to the laboratory, cooperating water utilities, and the travel of the authors. The results of the study show that the rapid ATP assay is highly correlated with the conventional plate count method and the DVC method, and estimates the bacterial quality of drinking water in minutes.
\end{abstract}

\section{INTRODUCTION}

The current microbiological standards focus on a single group of indicator organisms for the bacteriological safety of drinking water (Federal Register 1996). Although the current standards of water quality have eliminated massive outbreaks of waterborne disease, a question has been raised about the adequacy of the standards of drinking water quality to prevent water-borne illnesses (Payment et al. 1991). Cases of gastrointestinal illnesses were reported among individuals drinking tap water that had met microbiological and physico-chemical

Journal of Rapid Methods and Automation in Microbiology 7 (1999) 135-145. All Rights Reserved. - Copyright 1999 by Food \& Nutrition Press, Inc., Trumbull, Connecticut. 
water quality criteria (Payment et al. 1991). The determination of the total number of heterotrophic bacteria has been known as a better indicator of water quality than the coliform test because many opportunistic pathogens are not in the coliform group (Geldreich et al. 1972) and a high HPC has shown to interfere with the determination of the coliforms (LeChevallier et al. 1985).

The present HPC method using R2A agar is known as the most sensitive test for enumerating bacteria from treated water (Reasoner $e t$ al. 1985). The disadvantage of the test is that it takes seven days to complete. Unfortunately, when the results are known, the water that was tested has long been consumed. A test is needed that determines the total bacterial populations in a very short time so that corrective actions can be taken before the water is consumed. Such a test is useful in the operation of a water treatment plant, the monitoring of the distribution system, the installation of new pipes, and the repair of old pipes. An additional application includes a potential investigation of an outbreak of a suspected waterborne illness to pinpoint the locations with high bacterial counts. If the information is available on a timely basis, control measures would be possible before the water is consumed. The control measures are increasing the disinfectant dose at the water treatment plant and removing water with a high bacterial level from the distribution system by opening some fire hydrants.

The ATP bioluminescence assay can serve this purpose. It allows an estimation of bacterial populations within minutes and it can be applied on site also. The estimation of the bacterial count based on the ATP of the water is not new. What is new is that our method is over 100 times more sensitive, requires one-hundredth of the sample volume, and is over 10 times faster than the ATP method mentioned in Standard Methods (1995; 9211C.1). Standard Methods indicate that the test requires one hour, one liter of water, and has a sensitivity of 100,000 cells $/ \mathrm{mL}$.

There have been studies in the literature that described failures and poor correlation between ATP and HPC (Holt 1997; Smith 1992). Such results were probably due to improper separation of the bacterial ATP from the nonbacterial ATP. On the other hand, a good correlation between ATP and HPC was reported when studying biofilms (Van der Kooij et al. 1995).

The purpose of this study was to determine if a rapid ATP assay could estimate the bacterial populations in a practical and timely manner. For quality control purposes and to test the accuracy of both the ATP and HPC test, a direct enumeration of the bacteria in a water sample was done using two epifluorescence methods. One was AODC method to enumerate the total number of bacteria, which include both the viable cells and the nonviable cells. The other was DVC method, which selectively enumerate viable bacteria. 


\section{MATERIALS AND METHOD}

\section{Water Samples}

Water samples were obtained from drinking water fountains or distribution system sampling locations in the United States and abroad. The samples in the United States were taken from locations in Michigan, Ohio, Illinois, Washington D.C., California, Colorado, Florida, Georgia, Oregon, Washington, Kentucky, Tennessee, Maryland, Texas and New York. Some of the samples were obtained from airports (Illinois, California, Oregon, Washington, Kentucky, Tennessee, Maryland, Texas, New York), and some were obtained from cooperating utilities (Michigan, Ohio, California, Colorado, Georgia, Florida). A number of samples were obtained from Hungary, Germany, Switzerland, Netherlands, Austria, United Kingdom, France, Ukraine, Lithuania, Japan, Korea, Egypt, Saudi Arabia, Argentina, Peru, Brazil, Panama, and Australia.

\section{Filtration of Water Samples}

A Filtravette ${ }^{\mathrm{TM}}$, which is a combination of a filter and a cuvette with pore size of $0.45 \mu \mathrm{m}$, was placed into a Swinex filter holder $(13 \mathrm{~mm}$, Millipore Corporation, Bedford, MA). A sterile syringe was used for drawing the water samples. The testing volumes of the water were between 0.1 and $10 \mathrm{~mL}$, based on the expected number of bacteria in the sample. The filter holder was screwed onto the syringe and the water sample was pushed through the filter. The Filtravette $^{\mathrm{TM}}$ was taken out from the filter holder and placed onto a sterile blotting paper. The remaining water inside the filtravette was removed with a specially converted $3 \mathrm{~mL}$ syringe by applying gentle air pressure.

\section{ATP Bioluminescence}

A somatic cell releasing agent (New Horizons Diagnostic Corporation [NHD], Columbia, MD) was used according to the manufacturer's instructions to lyse all nonbacterial cells and release ATP. Air pressure was used to remove the nonbacterial ATP through the filter. At this stage, the Filtravette ${ }^{\mathrm{TM}}$ retains bacteria on its surface, and the bacterial ATP remained within the bacterial cell membranes through this step of the procedure (Cutter et al. 1996; Siragusa et al. 1995). This filtration method after special pretreatment was shown to be the most suitable for removing nonbacterial ATP (Olsen 1991). The Filtravette ${ }^{\mathrm{TM}}$ was inserted into the microluminometer (Model 3550, NHD, Columbia, MD) (Fig. 1) and the bacterial cell releasing agent was then added according to the manufacturer's instructions to lyse the bacterial cells retained on the surface of the filter. The released bacterial ATP was mixed with $50 \mu \mathrm{L}$ of luciferin-luciferase (NHD, Columbia, MD) and the drawer of microluminometer was closed. 
The light emission was recorded after $10 \mathrm{~s}$ integration of the light impulses and the unit was relative light unit (RLU). The result was expressed as $R L U / \mathrm{mL}$ by dividing the RLU values by the filtered water volume. The detection limit and sensitivity of the luminometer was tested with serially diluted ATP solution (NHD, Columbia, MD). Distilled deionized water was used for the dilution and the $\mathrm{pH}$ was 7.8. The activity of the luciferin-luciferase was checked by using an ATP standard (NHD, Columbia, MD). The RLUs are proportional to the amount of ATP, and the amount of ATP is proportional to the number of viable bacteria (LeChevallier et al. 1993).

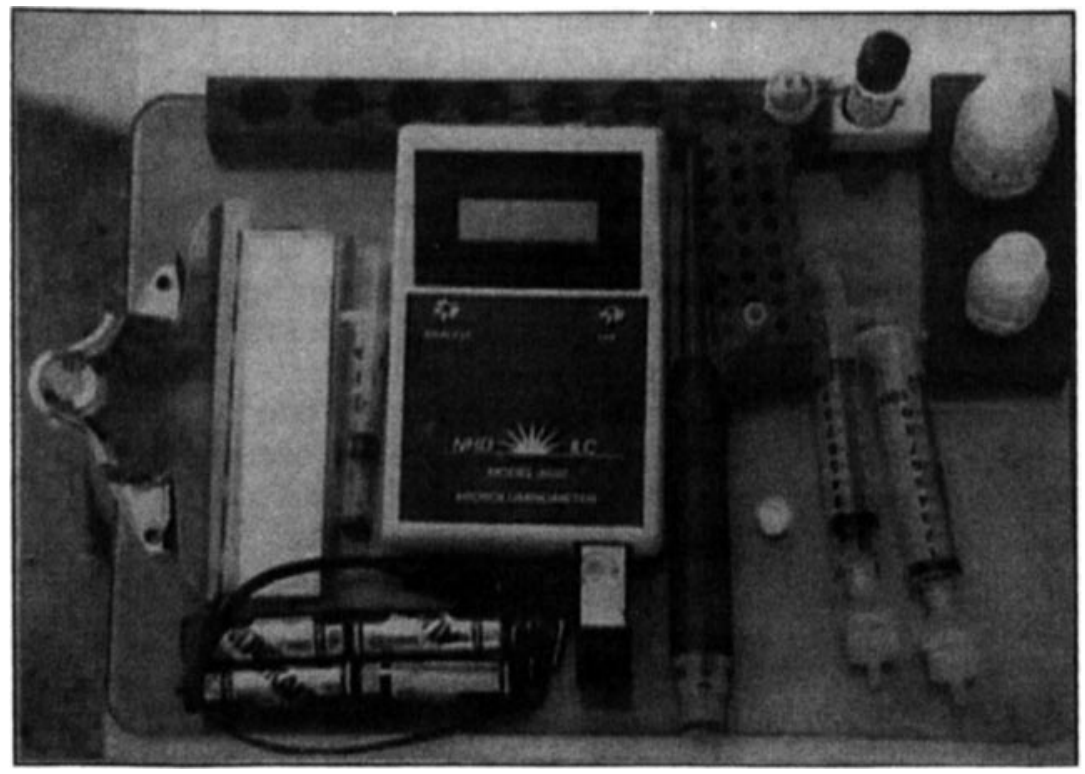

FIG. 1. THE MICROLUMINOMETER USED IN THE STUDY.

The picture shows the microluminometer, the portable power supply, a micropipette, syringes with the filter holder attached, the vial for the LL. a sterile blotting paper, and the botles with the solutions for lysing the somatic and bacterial cells. All the necessary equipment fits well onto a clipboard and into a briefcase.

Bacterial Enumeration: AODC, DVC, HPC

The total (nonviable and viable) bacterial cells were determined from formaldehyde fixed $(2 \%, v / v$, final concentration) samples with the AODC 
method (Hobbie et al. 1977). The bacterial cells were stained with acridine orange $(0.01 \%, \mathrm{w} / \mathrm{v}$, Fluka, Switzerland) after filtration onto a $0.2 \mu \mathrm{m}$-pore-size black polycarbonate membrane filters (Poretics, Livermore, CA). Cells were enumerated at a magnification of $\times 1000$ with an Olympus Provis epifluorescence microscope (Olympus Optical Co., Japan) equipped with a mercury arc lamp and a 460-490 nm excitation filter. The number of bacteria was counted in 10 microscopic fields using three subsamples and was then averaged. The number of bacteria per milliliter of sample was calculated using the equation in Standard Methods (APHA-AWWA-WEF 1995).

The viable cells were counted by the DVC method (Coallier et al. 1994) with some modifications. The samples were incubated with yeast extract $(0.005 \%, w / v$, Difco, Detroit, MI) and nalidixic acid $(10 \mathrm{mg} / \mathrm{L}$, Sigma, St. Louis, MO) without dilution for $24 \mathrm{~h}$ at $20 \mathrm{C}$. The modifications were using a lower concentration of yeast extract and no dilution. After incubation, the fixation, counting, and calculation of elongated bacteria were done following the AODC method.

The HPC was determined for each water sample in triplicate using R2A medium (Difco, Detroit, Michigan). The bacterial colonies were counted after an incubation period of 7 days at 28C (APHA-AWWA-WEF 1995).

\section{RESULTS AND DISCUSSION}

The detection limit of ATP was determined with high accuracy $(r=0.999)$ (Fig. 2). It showed that the microluminometer was able to determine ATP down to 0.2 picogram. It is known that the average ATP content in one bacterial cell is about $10^{-15} \mathrm{~g}$ (1 femtogram) (Crombrugge et al. 1991). Thus 0.2 picogram corresponds to 200 bacterial cells, which means the sensitivity of the ATP assay in terms of bacterial cell numbers.

About 120 water samples were analyzed with ATP bioluminescence method, HPC, DVC and AODC method, each in triplicate. The data show that there are high correlation coefficients between ATP, HPC, DVC, and AODC, and among those, the highest correlation coefficients were found between ATP and HPC $(0.84)$, and ATP and DVC $(0.80)$ (Table 1).

The relationship between ATP and HPC is shown in Fig. 3. In a number of cases where a cooperating utility sent water samples, the authors sent the expected HPC results by e-mail or fax on the day the water samples were received and analyzed. After the incubation period, the expected HPC and the measured HPC were compared. The expected HPC was calculated with the regression equation based upon the average $A T P(R L U / m L)$. For instance, if the average value is $10 \mathrm{RLU} / \mathrm{mL}$, the estimated $\mathrm{HPC}$ is $47 \mathrm{CFU} / \mathrm{mL}$ with a confidence interval $(\mathrm{Cl})$ between 32 (lower bound) and 71 (upper bound). In all 


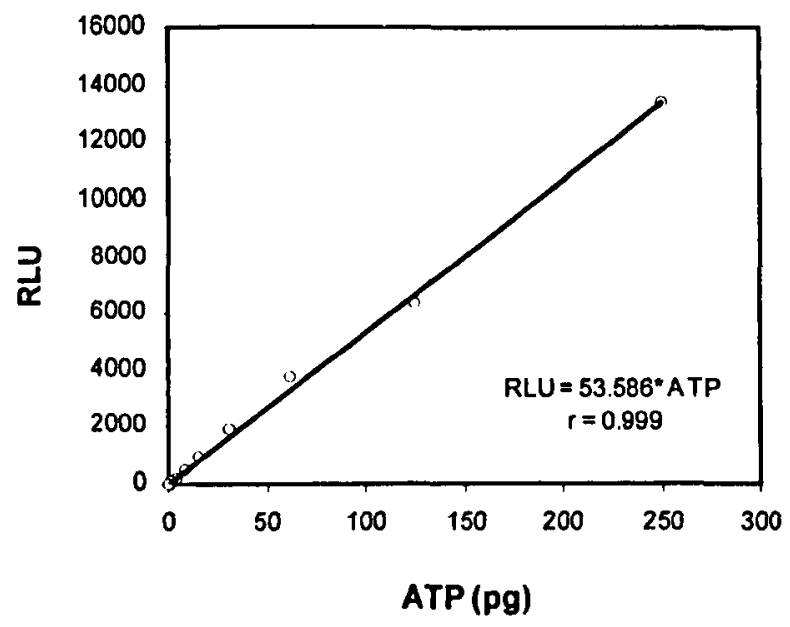

FIG. 2. THE DETECTION LIMIT AND SENSITIVITY OF THE LUMINOMETER The range of ATP concentration was between $0.2 \mathrm{pg}$ and $250 \mathrm{pg}$.

TABLE 1.

CORRELATION COEFFICIENTS BETWEEN ATP BIOLUMINESCENCE AND OTHER THREE PARAMETERS FOR DETERMINING BACTERIAL LEVEL IN DRINKING WATER

\begin{tabular}{lllll}
\hline & ATP & HPC & DVC & AODC \\
\hline ATP & 1 & - & - & - \\
HPC & 0.84 & 1 & & - \\
DVC & 0.80 & 0.75 & 1 & - \\
AODC & 0.68 & 0.66 & 0.73 & 1 \\
\hline
\end{tabular}

but a few cases, the prediction and the measured HPC by the utility agreed. The regression equation is $\log$ HPC $=0.35+1.470 * \log \operatorname{ATP}(n=114)$. A factor that may affect the linear relationship between ATP and HPC (CFU) is the presence of injured bacteria which cannot grow on agar plates. In treated drinking water, bacteria are exposed to disinfectants and a large proportion of the bacterial population became injured (McFeters et al. 1986; Camper et al. 1979). Injured bacteria are viable but are not able to form colonies on agar plates (LeChevallier et al. 1985); however, the injury does not directly affect the presence of intracellular ATP (Littel et al. 1986). The relation between the ATP and the DVC is shown in Fig. 4. Theoretically, when ATP is zero with no 


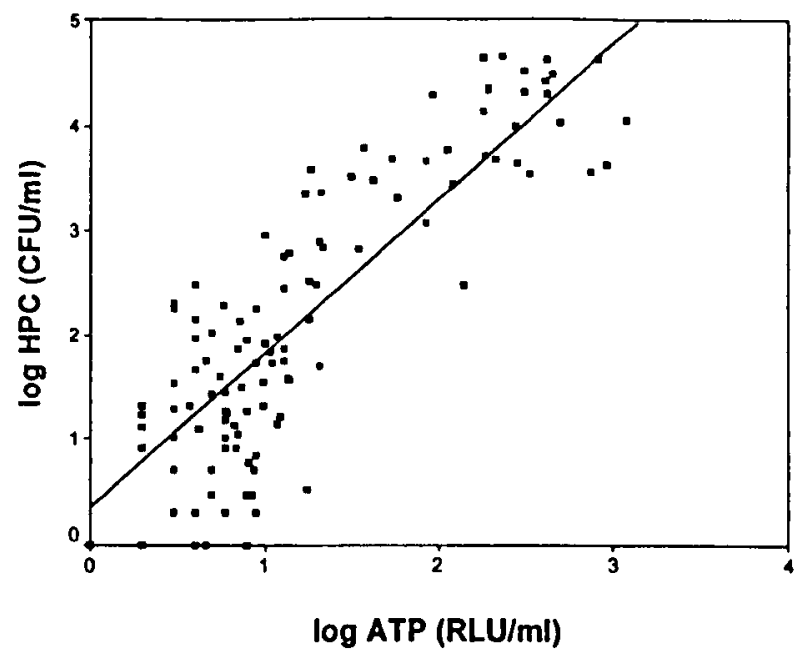

FIG. 3. RELATIONSHIP BETWEEN ATP AND HPC

The regression equation is: $\log \mathrm{HPC}=0.35+1.470 * \log \operatorname{ATP}(n=114, \mathrm{r}=0.84)$.

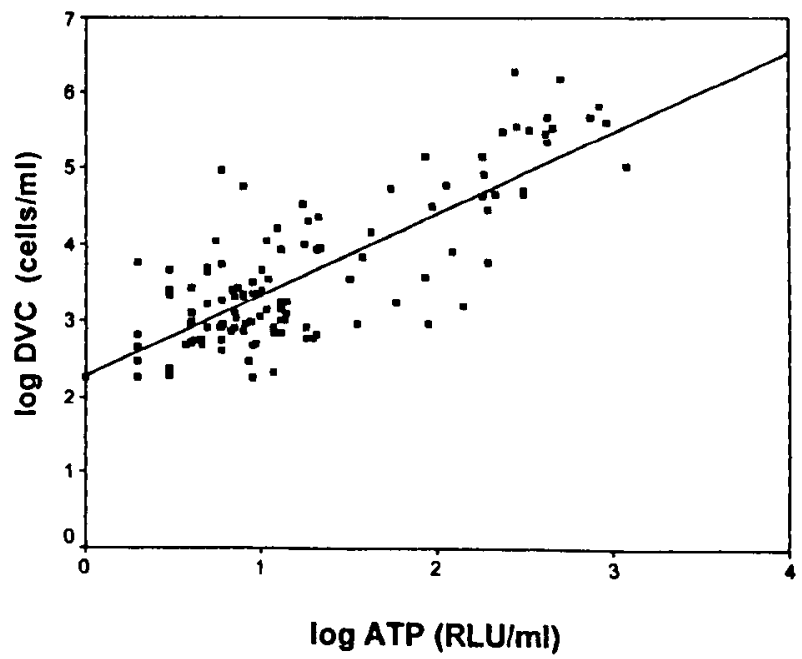

FIG. 4. RELATIONSHIP BETWEEN ATP AND DVC

The regression equation is: $\log \mathrm{DVC}=2.287+1.058 * \log$ ATP $(n=120, r=0.804)$. 
detectable light emission, the direct viable count should also be zero. The intercept of the regression equation of 2.287 (log scale), meaning 193 cells, indicates the detection limit of the procedure; it cannot be detected when the cell number is less than 193. This value is very similar to the number of 200 , which was obtained from the determination of the detection limit with ATP solution (Fig. 2). The relation between the HPC and the direct viable count is shown in Fig. 5. The fact that the regression line does not go through the origin indicates that even when the HPC is zero, there are viable bacteria present. Thus, the estimate is that there are $10^{2.43}$ per $\mathrm{mL}$, or about 270 bacterial cells which are viable, but not culturable on the R2A agar. The regression equation in Fig. 6 implies that when no detectable ATP occurs in the sample, a relatively large number of nonviable and viable cells are present and viewable using the acridine orange direct count method.

\section{CONCLUSIONS}

This is the first study where a miniaturized ATP bioluminescence method has been validated against the conventional plate method, the direct viable count, and the acridine orange direct count for the determination of heterotrophic bacteria in the drinking water samples. The ATP assay was found to be rapid

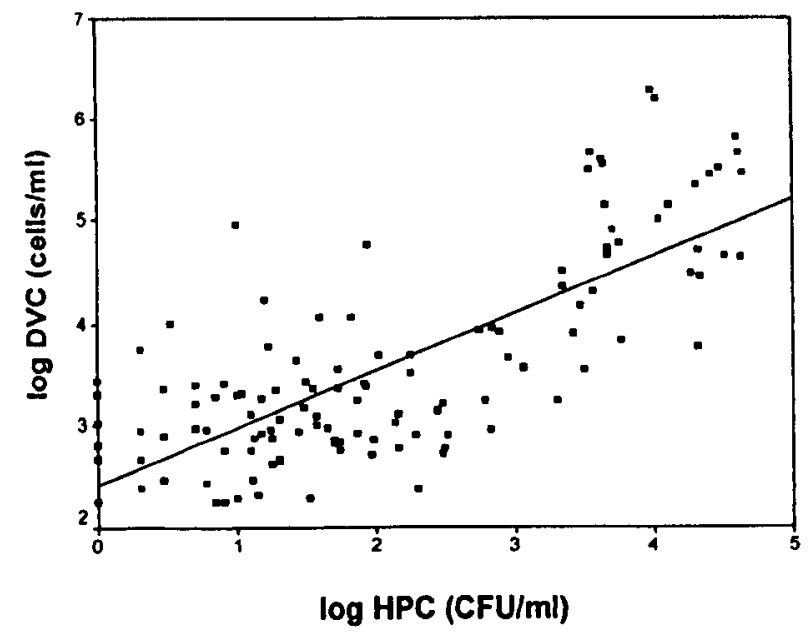

FIG. 5. RELATIONSHIP BETWEEN HPC AND DVC

The regression equation is: $\log D V C=2.43+0.56 * \log \mathrm{HPC}(n=121, r=0.75)$. 


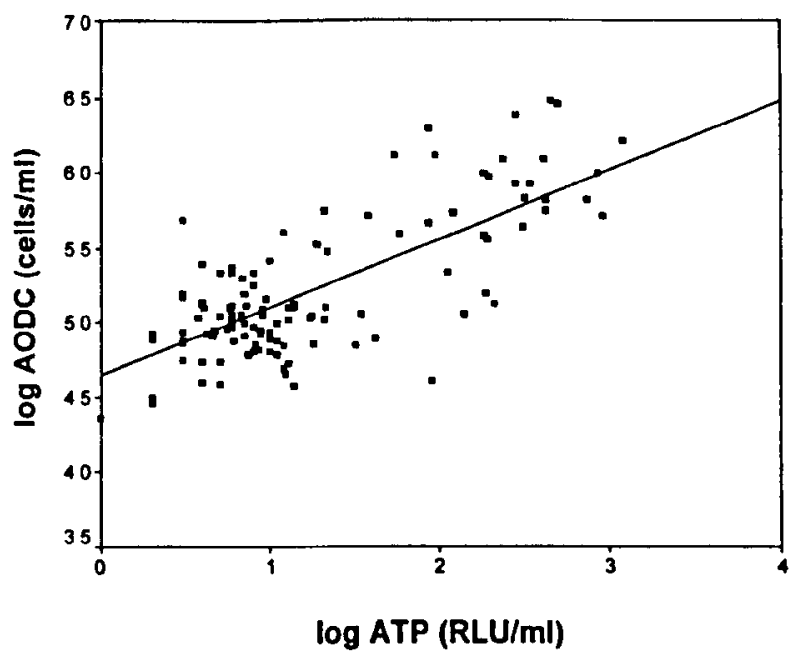

FIG. 6. RELATIONSHIP BETWEEN ATP AND AODC

The regression equation is: $\log A O D C=4.60+0.46 * \log \operatorname{ATP}(n=120 . r=0.68)$.

and sensitive. The procedure is simple and can be done on-site with a portable power supply. The volume of water for filtration is small $(0.1-10 \mathrm{~mL})$. It could be applied in many other fields, such as the bottled water industry, the food industry, and wastewater treatment plants. Other applications include testing the water for military troops when they are deployed to an area where the potability of available water is in question. It is also applicable to examine ultrapurified water used in the pharmaceutical industry and the electronics industry. Due to its small size and its high sensitivity, it can also be used as a tool to monitor the biological safety of water in a spacecraft.

\section{ACKNOWLEDGMENTS}

The authors are grateful for the participation of the water utilities that were involved in this study. In addition, the help provided by Dr. Martin Philbert and Dr. Peter G. Meier at the University of Michigan is sincerely appreciated. This project was partially funded by the Drinking Water Research Division, US EPA, Cincinnati, Ohio. 


\section{REFERENCES}

APHA-AWWA-WEF. 1995. Standard Methods for the Examination of Water and Wastewater. 19th Ed. American Public Health Association, Inc.. Washington, D.C.

CAMPER, A.K. and MCFETERS, G.A. 1979. Chlorine injury and the enumeration of waterborne coliform bacteria. Appl. Environ. Microbiol. 37, 633-641.

COALLIER, J., PREVOST, M. and ROMPRE, A. 1994. The optimization and application of two direct viable count methods for bacteria in distributed drinking water. Can. J. Microbiol. 40, 830-836.

CROMBRUGGE, J. and WAES, G. 1991. ATP method. In Methods for Assessing the Bacteriological Quality of Raw Milk from the Farm (W. Heeschen, ed.) pp. 53-60, International Dairy Federation, Brussels, Belgium.

CUTTER, C.N., DORSA, W.J. and SIRAGUSA, G.R. 1996. A rapid microbial ATP bioluminescence assay for meat carcasses. Dairy, Food and Environmental Sanitation. 16, 726-736.

Federal Register. 1996. Vol. 61. No. 94. 24372.

GELDREICH, E.E., NASH, H.D., REASONER, D.J. and TAYLOR, R.H. 1972. The necessity of controlling bacterial populations in potable waters; community water supply. J. Am. Water Works Assoc. 64, 596-602.

HOBBIE, J.E., DALEY, R.J. and JASPER, S. 1977. Use of Nuclepore filters for counting bacteria by fluorescence microscopy. Appl. Environ. Microbiol. 33, 1225-1228.

HOLT, D.M. and DELANOUE, A. 1997. ATP-can it measure bacteria in distribution systems. Proc. Water Quality Technology Conference. AWWA. Denver, Colorado.

LECHEVALLIER, M.W. and MCFETERS, G.A. 1985. Enumeration of injured coliforms in drinking water. J. Am. Water Works Assoc. 77, 81-87.

LECHEVALLIER, M.W. and MCFETERS, G.A. 1985. Interactions between heterotrophic plate count bacteria and coliform organisms. Appl. Environ. Microbiol. 49, 1338-1341.

LECHEVALLIER, M.W., SHAW, N.E., KAPLAN, L.A. and BOTT, T.L. 1993. Development of a rapid assimilable organic carbon method for water. Appl. Environ. Microbiol. 59, 1526-1531.

LITTLE, K.J. and LAROCCO, K.A. 1986. ATP screening method for presumptive detection of microbiologically contaminated carbonated beverages. J. Food Sci. 51, 474-476.

MCFETERS, G.A., KIPPIN, J.S. and LECHEVALLIER, M.W. 1986. Injured coliforms in drinking water. Appl. Environ. Microbiol. 51, 1-5. 
OLSEN, P. 1991. Rapid food microbiology: Application of bioluminescence in the dairy and food industry - a review. In Physical Methods for Microorganism Detection. (H. Wilfred, ed.) pp. 64-80, CRC Press, Boca Raton, Florida.

PAYMENT, P., RICHARDSON, L., SIEMIATYCKI, J., DEWAR, R., EDWARDES, M. and FRANCO, E. 1991. A randomized trial to evaluate the risk of gastrointestinal disease due to consumption of drinking water meeting current microbiological standards. 1991. Am. J. Public Health. 81, 703-708.

REASONER, D.J. and GELDREICH, E.E. 1985. A new medium for the enumeration and subculture of bacteria from potable water. Appl. Environ. Microbiol. 49, 1-7.

SIRAGUSA, G.R., CUTTER, C.N., DORSA, W.J. and KOOHMARAIE, M. 1995. Use of a rapid microbial ATP bioluminescence assay to detect contamination on beef and pork carcasses. J. Food Protection. 58, 770-775.

SMITH, E.S. and COLBOURNE, J.S. 1992. ATP rapid microbiology as a process control for slow sand filtration management. Proc. Water Quality Technology Conference. AWWA. Toronto, Ontario.

VAN DER KOOIJ, D., VEENENDAAL, H. R., BAARS-LORIST, C., VAN DER KLIFT, D.W. and DROST, Y.C. 1995. Biofilm formation on surfaces of glass and teflon exposed to treated water. Water Res. 29. $1655-1662$. 